\title{
Effect of Nitrogen and Potash on the Yield and Quality of Gladiolus (Gladiolus grandiflorus L) Flower
}

\section{Muhammad Zamin ${ }^{1 *}$, Abdullah Khan ${ }^{1}$ Ibadullah Jan', Fazli Rabbi ${ }^{2}$, Shahen Shah ${ }^{3}$, Rashid Ali', Kaleem Ullah $^{1}$ and Muhammad Amin ${ }^{4}$}

${ }^{1}$ University of Swabi, Khyber Pakhtunkbwa, Pakistan; ${ }^{2}$ University of Swat, Khyber Pakbtunkbwa, Pakistan; ${ }^{3}$ University of Agriculture, Peshawar, Khyber Pakhtunkhwa, Pakistan; ${ }^{4}$ Shaheed Benazir Bhotto University, Sharingal, Khyber Pakhtunkhwa, Pakistan.

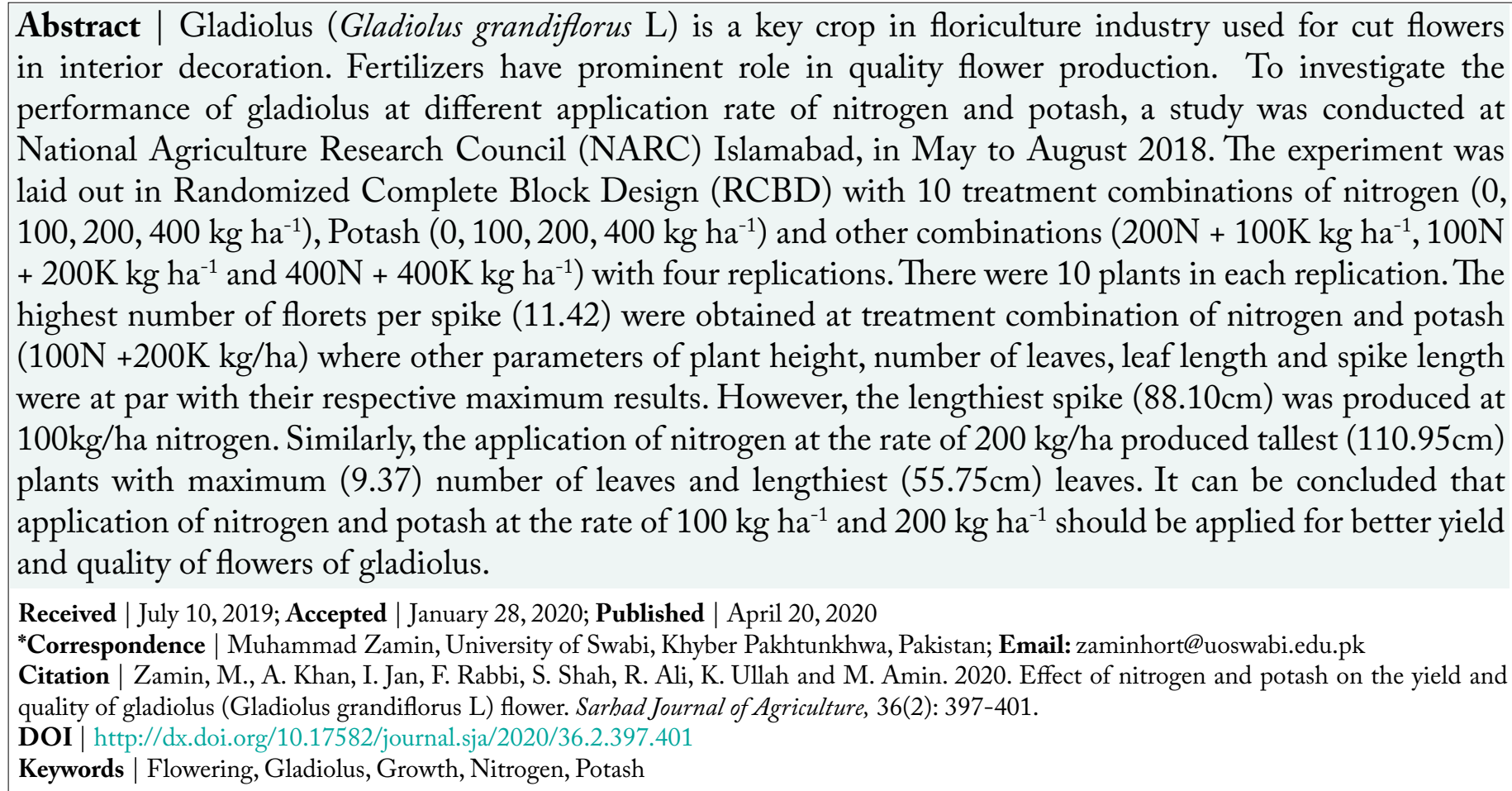

\section{Introduction}

G ladiolus (Gladiolus grandiflorous L) belongs to family iridaceae. It bears leaves which resemble sword, thus it was called gladiolus, meaning a sword in Latin Language. Commonly it is known as swordlilly (Khanam and Patra, 2015). Though, it was domesticated in 16th century, however, cultivated later in the 19th century in the Subcontinent (Rajput, 2003).

A significant part in horticulture is contributed by cut flowers industry. Maintaining quality of cut flowers for long time in florist shop, is considered very important in floriculture markets. Ethylene and micro-organisms are the key factors leading to senescence of flowers and ultimately adversely affecting shelf life of flowers (Zencirkiran, 2005).

Floriculture is an emerging industry in Pakistan and can improve economic status of small farmers. Each year 10000-12000 tons cut flowers are produced on national level. However, its demand is more than its production (Rehman, 2004). Roses are ranked on top June 2020 | Volume 36 | Issue 2 | Page 397 
in the national floriculture business while gladiolus is followed by it (Nadeem et al., 2011; Ramzan et al., 2010).

It is a great challenge for florists to improve longevity of cut flowers. This is because of vase life which is the important factors considered by consumers in addition to other quality parameters. Post-harvest life of gladiolus flowers is only four to six days which is considered a short duration in cut flower industry. The senescence florets remain at the bottom of the spikes once the upper florets are opened (Yamada et al., 2003).

Gladiolus is indigenous to the mountains of South America. They are widely grown in India. It is easy to grow, and is the favorite flower in India for bouquets. It has wide range of colors and bicolors. The flowers open from the bottom first. Normally spikes are harvested just before the top blossoms open. It is propagated from round shaped corms comprised of multi layers of tunics (Mukesh et al., 2001).

Plants produce food using complicated metabolic processes to fulfil the energy requirements for their survival. Mineral nutrients required during this process are obtained from soil in various forms (Bashir et al., 2016). Thus, plants growth depends upon the availability of these nutrients. A healthy plant can produce quality flowers. Nitrogen is the important nutrient contributing to improve vital processes. It is taken by roots in the form of nitrates available in the fertilizers (Ahmed et al., 2015).

That is why nitrogen is considered the main component of plant nutrition. In contrast to other essential nutrients, plants utilize a huge volume of Nitrogen because of its role in major biological activities. Since nitrogen is a major part of amino acids, DNA and Chlorophyll etc, therefore, its optimum availability to plants is a key in crop production and maintaining quality produce for competitive market (Chouhan et al., 2014). Inappropriate application of Phosphorus and Potash leads to few numbers of foliages and flowers with short stem and stunted growth in plants. Potassium is also essential for different vital activities such as activation of enzymatic activities. It also controls biosynthesis of protein. Studies on gladiolus show that it has significant role in number of days taken to spike emergence and opening of first flower (Bashir et al., 2016). The farmers are facing serious problems in gladiolus production such as they do not have proper recommendations for chemical fertilizers application and most of the times farmers are producing seeds without the application of any sort of fertilizers (Militiu et al., 2002). That is the result that they cannot produce the right sizes of corms or cormels for propagation. Thus, it is imperative to improve the yield of flowers and propagating materials using appropriate application of nitrogen and potash. Therefore, the study is designed to optimize the dose of Nitrogen and Potassium for growth, and flowering of gladiolus and to find the best combination of Nitrogen and Potassium for the better and quality production of gladiolus.

\section{Materials and Methods}

The research entitled "Effect of Nitrogen and Potash on the Yield and Quality of Gladiolus (Gladiolus grandiflorus L) Flower" was conducted at the ornamental nursery, Department of Horticulture, National Agriculture Research Council (NARC) Islamabad, during months of May-August 2018. The experiment was laid out in Randomized Complete Block Design (RCBD) having ten treatment combinations of nitrogen $\left(100 \mathrm{~kg} \mathrm{ha} \mathrm{k}^{-1}, 200 \mathrm{~kg} \mathrm{ha}^{-1}\right.$, $\left.400 \mathrm{~kg} \mathrm{ha}^{-1}\right)$, Murate of Potash $\left(100 \mathrm{~kg} \mathrm{ha}^{-1}, 200 \mathrm{~kg} \mathrm{ha}^{-}\right.$ $\left.1,400 \mathrm{~kg} \mathrm{ha}^{-1}\right)$ and other combinations $\left(200 \mathrm{~N} \mathrm{~kg} \mathrm{ha}^{-1}\right.$ $\left.+100 \mathrm{~K} \mathrm{~kg} \mathrm{ha}^{-1}\right),\left(100 \mathrm{~N} \mathrm{~kg} \mathrm{ha}^{-1}+200 \mathrm{~K} \mathrm{~kg} \mathrm{ha}^{-1}\right)$ and $\left(400 \mathrm{~N} \mathrm{~kg} \mathrm{ha}^{-1}+400 \mathrm{~K} \mathrm{~kg} \mathrm{ha}^{-1}\right)$ with four replications. One plot was kept as control where no fertilizers were applied. Gladiolus cultivar 'white prosperity' was used in the experiment. The field was thoroughly prepared and cleaned from weeds before planting the corms. The length of ridges was kept $100 \mathrm{~cm}$ and 10 cormlets were planted on a single ridge. The distance between cormlets placement was kept $10 \mathrm{~cm}$ and $30 \mathrm{~cm}$ distance between rows was maintained as per below lay out:

\begin{tabular}{lllll}
\multicolumn{5}{c}{ Field layout } \\
$\mathbf{T}$ & $\mathbf{R}_{1}$ & $\mathbf{R} 2$ & $\mathbf{R} 3$ & $\mathbf{R} 4$ \\
$\mathrm{~T}_{1}$ & $\mathrm{~T} 1 \mathrm{R} 1$ & $\mathrm{~T} 1 \mathrm{R} 2$ & $\mathrm{~T} 1 \mathrm{R} 3$ & $\mathrm{~T} 1 \mathrm{R} 4$ \\
$\mathrm{~T}_{2}$ & $\mathrm{~T} 2 \mathrm{R} 1$ & $\mathrm{~T} 2 \mathrm{R} 2$ & $\mathrm{~T} 2 \mathrm{R} 3$ & $\mathrm{~T} 2 \mathrm{R} 4$ \\
$\mathrm{~T}_{3}$ & $\mathrm{~T} 3 \mathrm{R} 1$ & $\mathrm{~T} 3 \mathrm{R} 2$ & $\mathrm{~T} 3 \mathrm{R} 3$ & $\mathrm{~T} 3 \mathrm{R} 4$ \\
$\mathrm{~T}_{4}$ & $\mathrm{~T} 4 \mathrm{R} 1$ & $\mathrm{~T} 4 \mathrm{R} 2$ & $\mathrm{~T} 4 \mathrm{R} 3$ & $\mathrm{~T} 4 \mathrm{R} 4$ \\
$\mathrm{~T}_{5}$ & $\mathrm{~T} 5 \mathrm{R} 1$ & $\mathrm{~T} 5 \mathrm{R} 2$ & $\mathrm{~T} 5 \mathrm{R} 3$ & $\mathrm{~T} 5 \mathrm{R} 4$ \\
$\mathrm{~T}_{6}$ & $\mathrm{~T} 6 \mathrm{R} 1$ & $\mathrm{~T} 6 \mathrm{R} 2$ & $\mathrm{~T} 6 \mathrm{R} 3$ & $\mathrm{~T} 6 \mathrm{R} 4$ \\
$\mathrm{~T}_{7}$ & $\mathrm{~T} 7 \mathrm{R} 1$ & $\mathrm{~T} 7 \mathrm{R} 2$ & $\mathrm{~T} 7 \mathrm{R} 3$ & $\mathrm{~T} 7 \mathrm{R} 4$ \\
$\mathrm{~T}_{8}$ & $\mathrm{~T} 8 \mathrm{R} 1$ & $\mathrm{~T} 8 \mathrm{R} 2$ & $\mathrm{~T} 8 \mathrm{R} 3$ & $\mathrm{~T} 8 \mathrm{R} 4$ \\
$\mathrm{~T}_{9}$ & $\mathrm{~T} 9 \mathrm{R} 1$ & $\mathrm{~T} 9 \mathrm{R} 2$ & $\mathrm{~T} 9 \mathrm{R} 3$ & $\mathrm{~T} 9 \mathrm{R} 4$ \\
$\mathrm{~T}_{10}$ & $\mathrm{~T} 10 \mathrm{R} 1$ & $\mathrm{~T} 10 \mathrm{R} 2$ & $\mathrm{~T} 10 \mathrm{R} 3$ & $\mathrm{~T} 10 \mathrm{R} 4$
\end{tabular}

All the cultural practices were carried out including irrigation. Data were taken for the following parameters:

June 2020 | Volume 36 | Issue 2 | Page 398 
Plant height $(\mathrm{cm})$

Measuring tape was used to take distance between bottom of the plant and tip of plant. Average was considered as the plant height.

\section{Number of leaves}

Few plants were selected randomly and leaves were counted in each plant. Total leaves were divided by number of plants selected to get average data for record.

\section{Leaflength (cm)}

Measuring tape was used to take total length of leaf blade. Maximum three leaves were measured for taking average leaf length.

\section{Spike length $(\mathrm{cm})$}

It was also measured by measuring tape in centimetre as above.

\section{Number of florets per spike}

Number of flowers sprouted were counted in randomly selected plants and recorded.

The data were analyzed via Statistix 8.1 software applying the analysis of variance (ANOVA) technique (Steel and Torrie, 1980). ANOVA was used to see the variance among the means using LSD test.

\section{Results and Discussion}

\section{Plant height $(\mathrm{cm})$}

Maximum (110.95 cm) plant height in Gladiolus was observed in treatment $\mathrm{T}_{3}$ followed by $\mathrm{T}_{2}(108.60 \mathrm{~cm})$ while minimum $(91.83 \mathrm{~cm})$ plant height was recorded in treatment T8 (Table 1). Nitrogen enhances plants vegetative growth resulting into increase in plant height. The above findings are matching with the results of Ahmed et al. (2015) in which they reported that, the application of Nitrogen and Potassium increase the height of gladiolus plant. Our results are far better than Ramzan et al. (2010) who found the tallest plants $(46 \mathrm{~cm})$ at combination of nitrogen 125 and potash $200 \mathrm{~kg} / \mathrm{ha}$ as compared to our tallest plants reaching $110.95 \mathrm{~cm}$.

\section{Number of leaves}

According to Table 1, maximum number of leaves were found in T3 (9.37) followed by T2 (9.20) while the least number of leaves (8.83) were produced by plants in T6. A non-significant effect was found between nitrogen and potash treatments. Our findings are in compliance with the results of Deswai et al. (2001) and Shah and Seth (2002). This parameter has direct relationship with plant height as higher the plant height more will be leaves. That is why the tallest plants at T3 also produced maximum leaves (De-Andrade-Porto et al., 2014).

\section{Leaflength $(\mathrm{cm})$}

Maximum leaf length $(57.09 \mathrm{~cm})$ was observed in T7 followed by T4 $(56.25 \mathrm{~cm}$ ) while minimum $(53.85 \mathrm{~cm})$ leaf length was found in $\mathrm{T} 1 \mathrm{which}$ is at par $(53.07 \mathrm{~cm})$ with T5 (Table 1). These results are in compliance with the findings of Bose and Yadav (2004) and Afifty (2003). They found similar trend of increased length of leaves at incremental doses of Nitrogen.

\section{Spike length (cm)}

Data in relation to spike length for various treatment combination of nitrogen and potash are presented in

Table 1: Effect of nitrogen and potash on plant height (cm), number of leaves, leaf length (cm), spike length (cm) and number of florets per spike of gladiolus flower.

$\begin{array}{llllll}\text { Treatments } & \begin{array}{l}\text { Plant } \\ \text { Height (cm) }\end{array} & \begin{array}{l}\text { No. of } \\ \text { Leaves }\end{array} & \begin{array}{l}\text { Leaf } \\ \text { Length (cm) }\end{array} & \begin{array}{l}\text { Spike } \\ \text { Length (cm) }\end{array} & \begin{array}{l}\text { No. of } \\ \text { Florets / Spike }\end{array} \\ \text { T1=Control } & 104.50 \mathrm{ab} & 8.92 \mathrm{ab} & 53.85 \mathrm{a} & 87.28 \mathrm{ab} & 9.75 \mathrm{ab} \\ \mathrm{T} 2=100 \mathrm{~kg} / \mathrm{ha} \mathrm{N} & 108.60 \mathrm{a} & 9.20 \mathrm{a} & 54.78 \mathrm{a} & 88.10 \mathrm{a} & 10.32 \mathrm{ab} \\ \text { T3=200 kg/ha N } & 110.95 \mathrm{a} & 9.37 \mathrm{a} & 55.75 \mathrm{a} & 81.80 \mathrm{ab} & 8.70 \mathrm{ab} \\ \text { T4=400 kg/ha N } & 104 \mathrm{~g} .13 \mathrm{ab} & 8.87 \mathrm{ab} & 56.25 \mathrm{a} & 76.81 \mathrm{abc} & 10.50 \mathrm{ab} \\ \text { T5=100 kg/ha K } & 100.45 \mathrm{ab} & 8.17 \mathrm{~b} & 53.07 \mathrm{a} & 82.62 \mathrm{ab} & 9.92 \mathrm{ab} \\ \text { T6=200 kg/ha K } & 96.02 \mathrm{ab} & 8.83 \mathrm{ab} & 54.33 \mathrm{a} & 74.75 \mathrm{bc} & 8.22 \mathrm{~b} \\ \text { T7=400 kg/ha K } & 101.00 \mathrm{ab} & 8.82 \mathrm{ab} & 57.09 \mathrm{a} & 77.52 \mathrm{abc} & 9.37 \mathrm{ab} \\ \text { T8=200 N +100 K kg/ha } & 91.83 \mathrm{~b} & 8.92 \mathrm{ab} & 55.42 \mathrm{a} & 66.45 \mathrm{c} & 8.57 \mathrm{~b} \\ \text { T9=100 N +200 K kg/ha } & 104.77 \mathrm{ab} & 8.75 \mathrm{ab} & 56.06 \mathrm{a} & 76.45 \mathrm{abc} & 11.42 \mathrm{a} \\ \text { T10=400 N + 400 K kg/ha } & 99.48 \mathrm{ab} & 9.10 \mathrm{ab} & 54.43 \mathrm{a} & 75.42 \mathrm{abc} & 9.35 \mathrm{ab}\end{array}$

June 2020 | Volume 36 | Issue 2 | Page 399 
Table 1. The means comparison indicated the spike length in descending order. The highest spike length $(88.10 \mathrm{~cm})$ was produced in T2 which was statistically higher than other treatments followed by $(87.28 \mathrm{~cm})$ recorded in T1. While minimum length of spike was recorded in T6 $(74.75 \mathrm{~cm})$ and T8 $(66.45 \mathrm{~cm})$. These results are in contrast to the findings of Anserwedekar and Patil (2004) who reported that the increased Nitrogen and Potash had remarkable effect on spike length.

\section{Number of florets per spike}

Means Table shows that maximum number of florets per spike (11.42) were observed in treatment T9 followed by (10.50) while minimum number of florets were recorded in treatment T8 (8.57). The least number of florets (8.22) were found in treatment T6. These findings are matching with the results of Lehri et al. (2011). They found that the application of Nitrogen and Potash in combination tended to improve the number of florets per spike.

\section{Conclusions and Recommendations}

Based on the research findings it is concluded that Nitrogen and Potash have varying effect on plant height, number of leaves, leaf length, spike length and number of florets per spike of gladiolus flower. The highest number of florets per spike (11.42) were obtained at treatment combination of nitrogen and potash $(100 \mathrm{~N}+200 \mathrm{~K} \mathrm{~kg} / \mathrm{ha})$. However, the lengthiest spike $(88.10 \mathrm{~cm})$ was produced at $100 \mathrm{~kg} / \mathrm{ha}$ nitrogen. Similarly, the application of nitrogen at the rate of $200 \mathrm{~kg} / \mathrm{ha}$ produced tallest $(110.95 \mathrm{~cm})$ plants with maximum (9.37) number of leaves and lengthiest $(55.75 \mathrm{~cm})$ leaves. Thus, it can be recommended that Nitrogen and Potash with combination of $100 \mathrm{~kg} \mathrm{ha}^{-1}$ nitrogen $+200 \mathrm{~kg} \mathrm{ha}{ }^{-1}$ potash is recommended for better growth and flowering of gladiolus.

\section{Novelty Statement}

High yield and better quality of Gladiolus grandiflorus, an important cut flower, can be enhanced using the best combination of nitrogen and potash in fertilizers. Please note that floriculture is an emerging business in Khyber Pakhtunkhwa, Pakistan

\section{Author's Contribution}

AK conducted the research as student. $\mathrm{MZ}$ performed overall paper write up and review. IJ designed the experiment and worked as supervisor. FR contributed in review of paper. SS and MA helped in data analysis and review of results. RA and $\mathrm{K}$ provide support in site related activities and data collection.

\section{References}

Afifty, M.M., 2003. Effect of high fertilizer rates on the growth, flowering and flower quality of three gladiolus cultivars. Hortic. Abstr. 12(4): 480.

Ahmed, S., S. Sultana, M.A. Kawochar, S. Naznin and F.U. Tuli. 2015. Effect of Corm Size and Nitrogen on the Growth and Flowering of Gladiolus (Gladiolus grandiflorous L.). Emer. Life Sci. Res., 1(1), 18-25

Anserwedekar, K.W. and V.K. Patil. 2004. Effect of NPK and spacing on vase life of gladiolus Cv. M.B. Pitt. Acta Hortic. Abstr. 181: 279-283.

Bashir, M., I. Khan, R.W.K. Qadri, M. Tanveer, M. Zain and I. Ahmad. 2016. Growth and Corm Production of Gladiolus grandiflorus L.'Essential'Under Different NPK Regimes. J. Ornamental Hortic. Plants, 6(1): 11-19.

Bose, T.K. and L.P. Yadav. 2004. Influence of potassium fertilizer rate and form on photosynthesis and N2-fixation of alfa alfa. Crop Sci.21: 481-485.https://doi.org/10.2135/ cropsci1981.0011183X002100040001x

Chouhan, P., M. Vidhyasankar and V. Rathore. 2014. Effect of NPK on Physico-Chemical Parameters of Gladiolus (Gladiolus bybridus Hort.) cv. White Prosperity. Int. J. Sci. Res. Publ. 4(12): 1-5.

De-Andrade-Porto, R.M. Koetz, E.M. BonfimSilva, A.C. Polizel, and T.J.A. da-Silva. 2014. Effects of water replacement levels and nitrogen fertilization on growth and production of gladiolus in a greenhouse. Agric. Water Manage.,131:50-56.https://doi.org/10.1016/j. agwat.2013.09.007

Deswai, K.S., V.K. Patil and K.W. Anserwedekar. 2001. Effect of nitrogen, phosphorus, potassium and plant density on the growth and flowering of gladiolus. Biol. Abstr. 79(1): 3813.

Khanam, R. and S.K. Patra. 2015. Effect of gravity drip irrigation on growth, yield and water use efficiency of gladiolus in lower gangetic plain of west Bengal, India. Int. J. Ecosyst., 5: 132-137.

Lehri, S.M., A.A. Kurd, M.A. Rind, and N.A. Bangulzai. 2011. The response of Gladiolus 
tristis L. to $\mathrm{N}$ and P2O5 fertilizers. Sarhad J. Agric., 27(2): 185-188.

Militiu, A., E. Vierasu and A.F. Iliescus. 2002. Influence of chemical fertilizers on flower quality and bulb production in Gladiolus. Hortic. Abstr. 42(1): 2975.

Mukesh, K., T.K. Chattopadhyay and M. Kumar. 2001. Effect of NPK on yield and quality of gladiolus (Gladiolus grandiflorus) cv. Trop. Sea. Environ. Ecol., 19: 868-871.

Nadeem, M., M.A. Khan, A. Riaz and R. Ahmad. 2011. Evaluation of growth and flowering potential of Rosa hybrida cultivars under Faisalabad climatic conditions. Pak. J. Agric. Sci., 48: 283-288.

Rajput, C., 2003. Floriculture in India. Dept. Agric. CSK Himachal Pradesh Krishi Viishvaid Yalaya Palampur, India-176062.

Rehman, F., 2004. Improvement of the vase life of cut gladiolus flowers by salicylic acid and Putrescine. In. j. of Advance. Biol. Biomed. Res. 2(2): 417-426.
Ramzan, A., I.A.Hafiz, T. Ahmad and N.A. Abbasi. 2010. Effect of priming with potassium nitrate and dehusking on seed germination of gladiolus (Gladiolus alatus). Pak. J. Bot., 42(1): 247-258.

Shah, L.A. and J.N. Seth. 2002. Effect of different levels of nitrogen and phosphorus on growth, flowering and corm yield of gladiolus. Progress. Hortic. 16(3): 305-307.

Steel, R.G. and J.H. Torrie. 1980. Principles and procedures of statistics, a biometrical approach (No. Ed. 2). McGraw-Hill Kogakusha, Ltd.

Yamada, T., Y. Takatsu, T. Manabe, M. Kasumi and W. Marubashi. 2003. Suppressive effect of trehalose on apopotic cell death leading to petal senescence in ethylene insensitive flowers of gladiolus. Plant Sci., 164: 213-222. https://doi. org/10.1016/S0168-9452(02)00403-X

Zencirkiran, M., 2005. Effect of sucrose and silver thiosulphate pulsing on stem- base cracking and vase life in Leucojum aestivum L. flowers. J. Hortic. Sci. Biotech. 80(3):332-334. https:// doi.org/10.1080/14620316.2005.11511939 